University of Nebraska - Lincoln

DigitalCommons@University of Nebraska - Lincoln

$11-1-1996$

\title{
Transmittance and Reflectance Measurements of Corn Leaves from Plants with Different Nitrogen and Water Supply
}

James S. Schepers

University of Nebraska-Lincoln, james.schepers@gmail.com

T. M. Blackmer

University of Nebraska-Lincoln

Wallace Wilhelm

University of Nebraska-Lincoln, wwilhelm1@unl.edu

M. Resende

Soil Scientist, EMBRAPA, CNP Milho e Sorgo, Sete Lagoas, MG-Brazil

Follow this and additional works at: https://digitalcommons.unl.edu/usdaarsfacpub

Part of the Agricultural Science Commons

Schepers, James S.; Blackmer, T. M.; Wilhelm, Wallace; and Resende, M., "Transmittance and Reflectance Measurements of Corn Leaves from Plants with Different Nitrogen and Water Supply" (1996).

Publications from USDA-ARS / UNL Faculty. 99.

https://digitalcommons.unl.edu/usdaarsfacpub/99

This Article is brought to you for free and open access by the U.S. Department of Agriculture: Agricultural Research Service, Lincoln, Nebraska at DigitalCommons@University of Nebraska - Lincoln. It has been accepted for inclusion in Publications from USDA-ARS / UNL Faculty by an authorized administrator of DigitalCommons@University of Nebraska - Lincoln. 


\title{
Transmittance and Reflectance Measurements of Corn Leaves from Plants with Different Nitrogen and Water Supply
}

\author{
J. S. Schepers ${ }^{1}$, T. M. Blackmer ${ }^{2}$, W. W. Wilhelm ${ }^{3}$, and M. Resende ${ }^{4}$ \\ ${ }^{1}$ Soil Scientist, USDA-ARS, University of Nebraska Lincoln, NE, 68583-0915 \\ ${ }^{2}$ Research Associate, USDA-ARS, University of Nebraska, Lincoln, NE 68583-0915 \\ ${ }^{3}$ Plant Physiologist, USDA-ARS, University of Nebraska, Lincoln, NE 68583-0915 \\ ${ }^{4}$ Soil Scientist, EMBRAPA, CNP Milho e Sorgo, Sete Lagoas, MG-Brazil
}

Received July 20, 1995 . Accepted October 30, 1995

\section{Summary}

Nitrogen is essential for crop production, but also contributes to eutrophication of surface water and degradation of drinking water quality. Modern corn production requires relatively large quantities of $\mathrm{N}$, which are generally supplied by fertilizers. Over-application of $\mathrm{N}$ fertilizers and animal wastes frequently results in nitrate leaching. Synchronizing $\mathrm{N}$ availability with crop $\mathrm{N}$ need offers the potential to protect the environment without sacrificing production. Tools are needed to rapidly and easily monitor crop $\mathrm{N}$ status to make timely decisions regarding fertilizer application. Analytical and optical techniques were evaluated with greenhouse grown corn at silking to evaluate several methods to monitor crop $N$ status. A portable chlorophyll meter was used to measure chlorophyll content of leaves by means of transmittance measurements. Leaf $\mathrm{N}$ concentration and chlorophyll meter readings were positively correlated, but were also affected by water stress and hybrid differences. Water stress decreased chlorophyll meter readings but increased leaf $\mathrm{N}$ content and diffusive resistance. Nitrogen stress decreased leaf $\mathrm{N}$ concentration, chlorophyll meter readings, and diffusive resistance. Both water and $\mathrm{N}$ stresses affected crop reflectance measurements. Reflectance values in the green and near IR portions of the spectrum were inversely related to crop $\mathrm{N}$ status. Water stress increased reflectance in red, green, and near IR wavelengths. Water stress by $\mathrm{N}$ status interactions were significant for chlorophyll meter readings as well as reflectance measurements. Both leaf reflectance and chlorophyll meter measurements provided a good indication of $\mathrm{N}$ status for adequately watered plants, but the relationships were poor for plants grown under prolonged water stress.

Key words: Maize, transmittance, reflectance, nitrogen fertilizer, water stress.

Abbreviations: $\mathrm{N}=$ nitrogen; $\mathrm{C}=$ carbon; $\mathrm{W}=$ water stress; $\mathrm{VT}=$ stage of corn growth after complete tassel emergence but before silk emergence.

\section{Introduction}

Nitrogen $(\mathrm{N})$ fertilizer management in modern corn production is an important area of applied research that has both economic and environmental consequences. Tissue testing is one tool that can aid in fertilizer management by identifying crop requirements for additional $N$. Measuring leaf optical properties (i.e., reflectance or transmittance) of radiant energy can be considered a form of tissue testing.

Variation in plant pigmentation can be caused by many factors, but nutrient stress is generally a primary consideration. Maas and Dunlap (1989) used reflectance measurements to characterize pigmentation differences between leaves of untreated corn plants, leaves of fluridone-induced 
albino plants, and leaves from etiolated plants (various lengths of darkness) that had different chlorophyll concentrations. In another study, Al-Abbas et al. (1974) used reflectance measurements to demonstrate that deficiencies of $\mathrm{N}, \mathrm{P}$, $\mathrm{K}, \mathrm{Mg}, \mathrm{S}$, and $\mathrm{Zn}$ in corn leaves affected leaf pigmentation and chlorophyll concentrations. Other research has shown that leaf reflectance measured at $550 \mathrm{~nm}$ from sweet pepper (Capsicum annum $\mathrm{L}$.) leaves had a strong relationship with $\mathrm{N}$ concentration (Thomas and Oerther, 1972). They concluded leaf reflectance at $550 \mathrm{~nm}$ was a good indicator of leaf chlorophyll content. More recently, others have also shown reflectance measurements can be a good indicator of $\mathrm{N}$ stress in corn leaves (McMurtrey et al., 1994; Blackmer et al., 1994).

Chlorophyll meters have been shown to be effective at detecting $\mathrm{N}$ stress in corn (Zea mays L.) leaves (Schepers et al., 1992 a; Wood et al., 1992; Blackmer et al., 1994). Although transmittance measurements with the Minolta ${ }^{1}$ SPAD-502 chlorophyll meter are rapid and easy to make, they represent only a very small portion of a leaf. The closed chamber created when the chlorophyll meter is clamped onto the leaf eliminates interferences by external light sources. On the other hand, an integrating sphere is essentially a larger and more versatile type of chlorophyll meter (also closed system with internal lighting). An integrating sphere not only measures leaf transmittance, but it also measures reflectance at many wavelengths. A major difference between the two instruments is that the Minolta chlorophyll meter measures specific wavelengths (centered at 650 and $940 \mathrm{~nm}$ ) while the integrating sphere can measure many wavelengths in small increments.

Reflectance measurements can also be made beyond the single leaf confines of an integrating sphere. When canopy reflectance measurements are made, external or natural light sources are used. Variation in external lighting requires special calibration procedures. The advantage of reflectance measurements is that when made from above the canopy, they represent a large area relative to a single leaf. Reflectance measurements made near the crop canopy integrate plant-to-plant variation, while those taken a greater distance from the crop will integrate a larger area. Depending on the field of view of the instrument, measurements taken well above the canopy should make it possible to identify atypical areas in a field.

Leaf pigments (e.g., carotenoids and anthocyanins) absorb various amounts of light in the visible range of the spectrum. These leaf characteristics influence the reflectance signature of crops. Reflection of visible light $(400-700 \mathrm{~nm})$ from vegetative tissue, like a corn leaf, is least at wavelengths where chlorophyll absorption is greatest. This phenomena results in characteristically greater reflectance around $550 \mathrm{~nm}$ and lower reflectance around 450 and $650 \mathrm{~nm}$. In combination, these absorption/reflection characteristics result in relatively large differences in light reflection compared to relatively small fluctuations in chlorophyll concentrations. It follows that leaf reflectance in the visible portion of the spectrum is indicative of chlorophyll concentration (Benedict and Swidler, 1961; Sinclair et al., 1971) and carotenoid concentration (Thomas and Gausman, 1977).

Water stress can increase reflectance from corn leaves in both the visible and near infrared portions of the spectrum (Wooley, 1971). Previous research has shown that $\mathrm{N}$ concen- tration and chlorophyll content are affected by both $\mathrm{N}$ and water stress (Wolfe et al., 1988). They found leaf chlorophyll concentration in corn showed a water stress by $\mathrm{N}$ stress interaction, however, leaf $\mathrm{N}$ concentration was not affected by the interaction. This is probably because leaf $\mathrm{N}$ concentration is related to the $\mathrm{N}$ uptake process whereas chlorophyll content is predominantly a metabolic parameter.

The objective of this study was to evaluate the effect of water stress on monitoring crop $\mathrm{N}$ status by tissue and optical methods. The approach was to utilize data from a variety of analytical procedures in an attempt to better characterize the interactions between $\mathrm{N}$ and water stresses.

\section{Materials and Methods}

This greenhouse study was established on 2 August 1993. Three replications of Pioncer brand hybrids ${ }^{1} 3398$ and 3379 were planted into pots $30-\mathrm{cm}$ diameter by $30-\mathrm{cm}$ depth. Artificial lighting was provided to extend the day length. Three levels of $N$ (low, near adequate, and somewhat excessive) were established prior to planting by applying ammonium nitrate and lightly watering into the potting media which consisted of equal parts of sand, soil, peat moss, and vermiculite. After germination, seedlings were thinned to four per pot. Plants in all pots were maintained in a well watered state (minimum of $50 \%$ of water holding capacity) until the V6 growth stage (Ritchie et al., 1992), when two water regimes were established. Plants in one treatment were well watered while plants in the second treatment were allowed to become stressed. Water stress was imposed by reducing the watering frequency. Diffusive resistance was measured to qualitatively determine watering frequency.

At the VT growth stage (21 September), water and N-related measurements were made on the ear leaf of two of the original four plants in each pot. For N-related measurements, thirty chlorophyll meter readings were taken with a Minolta SPAD 502 chlorophyll meter from midway along the length of the ear leaf and midway between the margin and midrib of two plants (Peterson et al., 1993). The same position on these leaves was used to make spectral reflectance measurements using a $\mathrm{Li}-\mathrm{Cor}^{1}$ integrating sphere with a halogen white light source. $\mathrm{A} \mathrm{BaSO}_{4}$ reference was used to calibrate all reflectance measurements. Each spectral scan was composed of reflectance from 512 bands between 348 and 1070 -nm wavelengths in 1.4-nm increments. Approximately $350 \mathrm{~ms}$ were used to complete each spectral scan. Data from selected wavelengths $(550,650,710$, 850 , and $940 \mathrm{~nm}$ ) were used for statistical analysis.

Water related measurements included diffusive resistance, made on the ear leaf using a $\mathrm{Li}-\mathrm{Cor}^{1}$ model 1600 steady state porometer. After chlorophyll meter, reflectance and diffusive resistance measurements were made, the same area of the same leaves was semi-destructively sampled using a $1-\mathrm{cm}$ dia. leaf punch. A total of 40 disks were collected between the margin and midrib from both plants in each pot. Leaf disks were dried, weighed, and finely ground (200 mesh) prior to analysis for $\mathrm{C}$, total $\mathrm{N}$, and ${ }^{15} \mathrm{~N}$ using a Carlo Erba NA1500 CNS analyzer coupled to a Europa tracermass mass spectrometer (Schepers et al., 1989). Even though ${ }^{15} \mathrm{~N}$ fertilizer was not applied in this study, the analyzer system automatically provided isotopic data.

Analysis of variance was performed on all data using the general linear model procedures of SuperANOVA software (Abacus Concepts, Inc., 1989).

\footnotetext{
${ }^{1}$ Mention of brand names does not indicate an endorsement by the USDA-ARS.
} 


\section{Results and Discussion}

Statistical analysis indicated that leaf $\mathrm{N}$ concentration was affected by hybrid, $\mathrm{N}$ rate, and water stress (Table 1). These findings are consistent with trends commonly noted in the literature (Schepers et al., 1992 b). Chlorophyll meter readings are typically affected by the same factors that affect leaf $\mathrm{N}$ concentration. Differences in chlorophyll meter readings between hybrids were significant at $\mathrm{P}=0.055$. Both $\mathrm{N}$ and water stresses reduced chlorophyll meter readings. Water stress had a considerable effect on chlorophyll meter readings when adequate $N$ was available, but had little effect when $N$ was limiting plant growth (Fig. 1).

Earlier studies (Blackmer et al., 1994; Schepers et al., 1992 a) did not address the influence of water stress on

Table 1: Means and statistical significance of fertilizer $\mathrm{N}$ rate, water stress, and cultivar on leaf $\mathrm{N}, \mathrm{C}$, and ${ }^{15} \mathrm{~N}$ content, chlorophyll meter readings, and diffuse resistance.

\begin{tabular}{|c|c|c|c|c|c|}
\hline Variable & $\begin{array}{l}\text { Nitrogen } \\
(\mathrm{mg} / \mathrm{g})\end{array}$ & $\begin{array}{l}\text { Carbon } \\
(\mathrm{mg} / \mathrm{g})\end{array}$ & $\begin{array}{l}{ }^{15} \mathrm{~N} \\
\text { atom } \%\end{array}$ & $\begin{array}{l}\text { Chlorophyll } \\
\text { meter } \\
\text { (reading) }\end{array}$ & $\begin{array}{l}\text { Diffuse } \\
\text { resistance } \\
(\mathrm{s} / \mathrm{cm})\end{array}$ \\
\hline \multicolumn{6}{|l|}{ Hybrid } \\
\hline 3379 & 26.7 & 426 & 0.378 & 42.9 & 348 \\
\hline 3398 & 29.6 & 419 & 0.375 & 44.0 & 55 \\
\hline \multicolumn{6}{|l|}{$N$ rate } \\
\hline low & 19.6 & 410 & 0.384 & 37.0 & 9 \\
\hline medium & 30.9 & 426 & 0.374 & 44.5 & 209 \\
\hline high & 34.0 & 431 & 0.372 & 48.9 & 386 \\
\hline \multicolumn{6}{|l|}{ Water status } \\
\hline stressed & 29.2 & 422 & 0.376 & 41.1 & 397 \\
\hline nonstressed & 27.1 & 423 & 0.377 & 45.7 & 6 \\
\hline \multicolumn{6}{|l|}{ Probability } \\
\hline Hybrid & $* *$ & 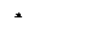 & $* *$ & ns & ns \\
\hline $\mathrm{N}$ rate & $* *$ & $* *$ & $* *$ & $* *$ & $\mathrm{~ns}$ \\
\hline Water stress (W) & $* *$ & ns & $\mathrm{ns}$ & $* *$ & $*$ \\
\hline Hybrid $\times N$ rate & $\mathrm{ns}$ & ns & $*$ & ns & ns \\
\hline $\mathrm{N}$ rate $\times \mathrm{W}$ & ns & ns & $\mathrm{ns}$ & $* * *$ & ns \\
\hline Hybrid $\times W$ & $* *$ & ns & ns & $\mathrm{ns}$ & ns \\
\hline Hybrid $\times N$ rate $\times W$ & ns & ns & $*$ & ns & ns \\
\hline
\end{tabular}

*, ** Significant at the 0.05 and 0.01 levels, significantly.

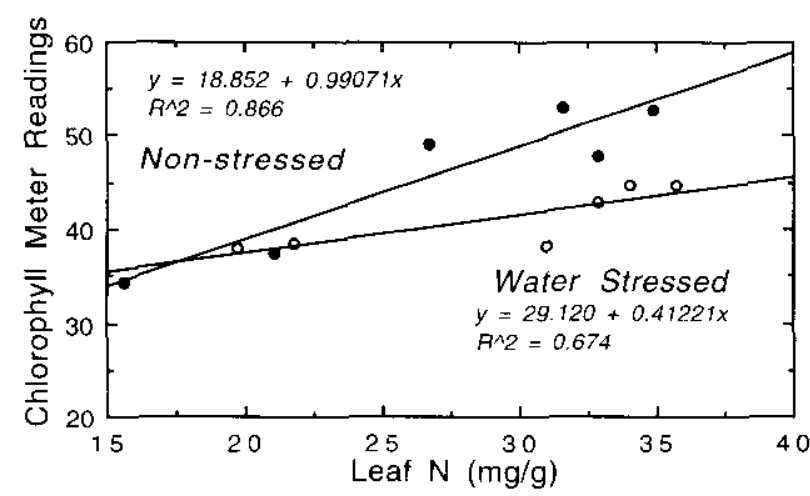

Fig. 1: Relationship between leaf $N$ concentration and chiorophyll meter readings of water stressed and adequately watered corn. chlorophyll meter readings although there was a strong positive correlation between leaf $\mathrm{N}$ concentration and chlorophyll meter readings. Data reported here resulted in only a weak to moderate correlation $(r=0.65)$ between leaf $\mathrm{N}$ concentration and chlorophyll meter readings when combined across two different water levels. The relationship between leaf $\mathrm{N}$ concentration and chlorophyll meter readings improved significantly by differentiating between levels of crop water status (Fig. 1). Adequate water increased both the chlorophyll meter reading response to $\mathrm{N}$ fertilizer and the correlation between meter readings and leaf $\mathrm{N}$ concentration.

Even though chlorophyll meter readings responded similarly to $\mathrm{N}$ for both hybrids in this study, other studies have indicated hybrids may have different chlorophyll meter readings when fertilized at the same $\mathrm{N}$ rate (Schepers et al., 1992 b). In this study, at the lowest fertilizer $\mathrm{N}$ level Pioneer brand hybrid 3398 contained $22 \%$ greater leaf $N$ concentration than 3379 across both water regimes, but showed only a $2 \%$ difference at the highest $\mathrm{N}$ rate (Table 1). The significant hybrid by water stress interaction occurred because leaf $\mathrm{N}$ concentration for 3398 was not affected by water stress, while that for 3379 showed an $18 \%$ increase in leaf $\mathrm{N}$ concentration with the water stress.

Several scenarios can be proposed to support the above trends in leaf $\mathrm{N}$ concentration. First, hybrid 3398 may be more efficient in terms of $\mathrm{N}$ uptake than 3379 resulting in greater leaf $\mathrm{N}$ concentrations. An alternative is that 3379 might be able to maintain growth at a lower leaf $\mathrm{N}$ concentration than 3398 and may partition a greater proportion of $\mathrm{N}$ to metabolite production. It is also possible that 3379 is more subject to volatile $\mathrm{N}$ losses from its tissue than 3398 or that 3398 is more effective at adsorbing ammonia from the atmosphere than 3379 (Francis et al., 1993). Some support for the volatilization scenario is provided by isotopic $\mathrm{N}$ data showing a greater ${ }^{15} \mathrm{~N}$ enrichment (i.e., above normal abundance levels) for 3379 than for 3398 (Table 1). For this scenario to be feasible and for 3379 to have a lower leaf $\mathrm{N}$ concentration than 3398 , it would probably require fractionation (i.c., preference for ${ }^{14} \mathrm{~N}$ vs. ${ }^{15} \mathrm{~N}$ or vise-versa) of $\mathrm{N}$ during volatilization. Fractionation also occurs when using the microdiffusion process to prepare samples for isotopic analysis (Hauck, 1982). As a result, in this case, a great proportion of ${ }^{14} \mathrm{~N}$ would be volatilized, thus leaving proportionately more ${ }^{15} \mathrm{~N}$ in the plant. This scenario could also account for lower leaf $\mathrm{N}$ concentrations for 3379 than for 3398 .

Occurrence and fate of $\mathrm{N}$ in the environment also involves ammonia absorption from the atmosphere by vegetation, which in some ways can be thought of as the reverse of $\mathrm{N}$ volatilization from leaves. Plants under the greatest $\mathrm{N}$ stress would have the greatest likelihood of absorbing atmospheric ammonia. If for some reason, the atmosphere was enriched with ${ }^{15} \mathrm{~N}$ ammonia or fractionation occurs during absorption, then the most $\mathrm{N}$ deprived plants might be expected to become enriched proportionately more than plants having adequate $\mathrm{N}$ availability.

Discussion of ${ }^{15} \mathrm{~N}$ abundance in the plant tissue is confounded because microbial processes tend to concentrate ${ }^{15} \mathrm{~N}$ in soil and manures through fractionation. Increased ${ }^{15} \mathrm{~N}$ abundance in leaf tissue can be explained by the fact that commercial $\mathrm{N}$ fertilizers tend to have a normal abundance of 
${ }^{15} \mathrm{~N}$ (i.e., 0.367 atom $\%{ }^{15} \mathrm{~N}$ ). In this case, a shortage of $\mathrm{N}$ fertilizer would result in proportionately greater uptake of residual soil $\mathrm{N}$, which could be enriched if the soil contained peat or had a history of manure application. This hypothesis is supported by the strong inverse correlation $(r=0.92)$ between leaf $\mathrm{N}$ concentration and atom $\%{ }^{15} \mathrm{~N}$ in the leaf. Further study would be required to characterize these processes.

The $\mathrm{C}$ content of plant tissue (Table 1 ) is typically about $400 \mathrm{mg} / \mathrm{g}$, plus or minus $10 \%$. Data from this study fall within this range, but showed a significant $\mathrm{N}$ rate and hybrid effect. No explanation is provided as to why leaf $\mathrm{C}$ concentration decreased with $\mathrm{N}$ availability other than perhaps it is related to a slight dilution of $\mathrm{C}$ content caused by enhanced $\mathrm{N}$ uptake or metabolite storage in the leaves. At the time of sampling, the position of the ear leaf was easy to identify and pollination was in progress, but it is unlikely that translocation of metabolites had occurred to a significant extent. This hypothesis is supported by leaf thickness calculations made from leaf disk weight and surface area data, assuming a constant density, which showed a lower leaf thickness for $\mathrm{N}$ stressed plants.

Diffusive resistance measurements generally showed more variability than the other measurements. Nonetheless, plant water stress resulted in greater diffusive resistance, which affects exchange of water vapor and gases with the atmosphere, thereby affecting plant metabolism and growth.

Hybrid differences in this study did not affect any of the reflectance values (Table 2 ). In contrast, nearly every value (i.e., specific wavelengths) was affected by $\mathrm{N}$ availability and water status. Reflectance increased with water stress for all wavelengths shown in Table 2. This finding was expected because of the effect water stress has on diffusive resistance and plant metabolism in general. It should be noted that reflectance at 850 and $940 \mathrm{~nm}$ decreased with $\mathrm{N}$ stress, but concurrently increased at 550 and $710 \mathrm{~nm}$ and showed mixed results at $650 \mathrm{~nm}$. These same measurements all showed an $\mathrm{N}$ stress by water stress interaction, which prompted a closer examination of the data than is evident from the mean values provided in Table 2 . Water stress on plants with adequate $\mathrm{N}$ increased reflectance at $550 \mathrm{~nm}$ but had little affect under $\mathrm{N}$ stressed conditions (Fig. 2). Reflectance at $650 \mathrm{~nm}$ was not affected by $\mathrm{N}$ status as long as the plants received adequate water, but water stress increased reflectance of plants with adequate $N$ (Fig. 2). Implications of these interactions are that interpretation of leaf reflectance data to evaluate crop $\mathrm{N}$ status is likely to be confounded by crop water status.

Since one of the goals of this research was to identify reflectance signatures (i.e., key wavelengths) that could provide similar information as the leaf transmittance measurements collected with the Minolta chlorophyll meter, reflectance data were compared with chlorophyll meter readings. Correlations between meter readings and individual wavelengths (Table 3) were the strongest for $550 \mathrm{~nm}$ (green color) and $710 \mathrm{~nm}$ (red edge area). Correlations decreased between these two wavelengths where corn plants were absorbing the highest proportion of light in the $650 \mathrm{~nm}$ portion of the spectrum (red light) (Table 2).

The lack of any meaningful relationship between chlorophyll meter readings and reflectance at either 850 or $940 \mathrm{~nm}$ (near infrared wavelengths) is typical because plants do not
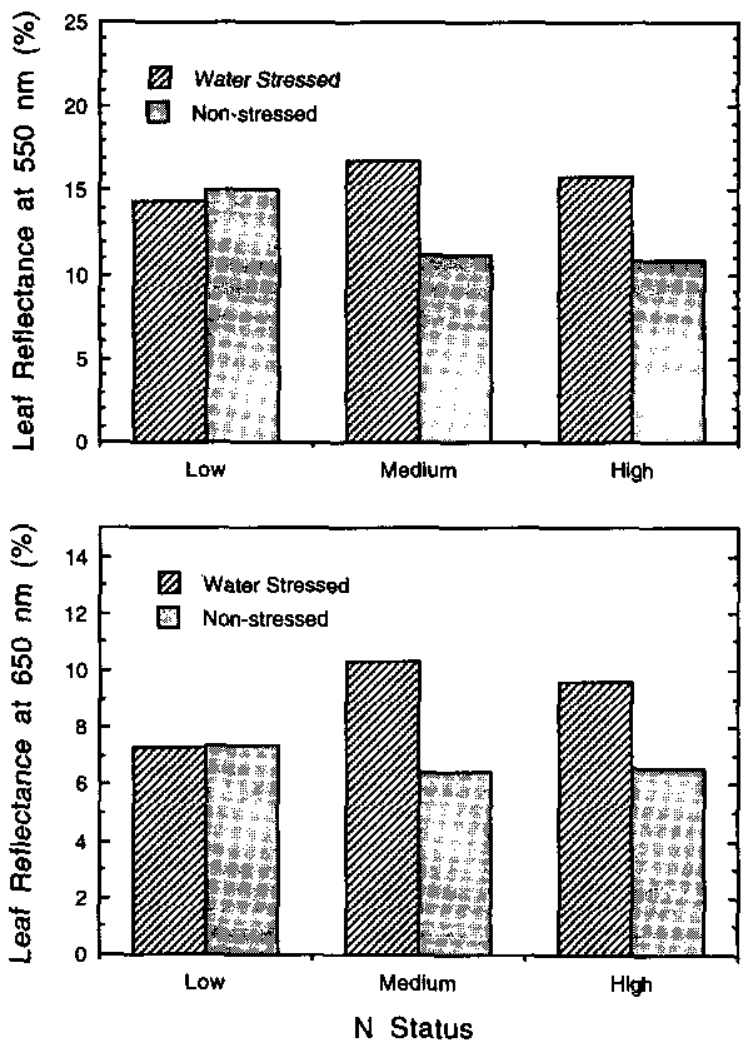

Fig. 2: Ear-leaf reflectance at 550- and 650-nm wavelengths of corn grown at three $N$ levels and under water-stressed and control conditions

Table 2: Mean values and statistical significance of fertilizer $\mathrm{N}$ rate, water stress and cultivar on crop reflectance measurements.

\begin{tabular}{|c|c|c|c|c|c|c|c|}
\hline \multirow[t]{2}{*}{ Factor } & \multicolumn{7}{|c|}{ Wavelength $(\mathrm{nm})$} \\
\hline & $\begin{array}{l}550 \\
(\%)\end{array}$ & $\begin{array}{l}650 \\
(\%)\end{array}$ & $\begin{array}{l}710 \\
(\%)\end{array}$ & $\begin{array}{l}850 \\
(\%)\end{array}$ & $\begin{array}{l}940 \\
(\%)\end{array}$ & $550 / 850$ & $710 / 850$ \\
\hline \multicolumn{8}{|l|}{ Hybrid } \\
\hline 3379 & 14.2 & 7.79 & 18.8 & 40.8 & 40.5 & 0.349 & 0.462 \\
\hline 3398 & 13.8 & 8.08 & 18.1 & 41.0 & 40.6 & 0.336 & 0.439 \\
\hline \multicolumn{8}{|l|}{$\mathrm{N}$ rate } \\
\hline low & 14.8 & 7.32 & 19.4 & 39.6 & 39.2 & 0.373 & 0.490 \\
\hline medium & 14.0 & 8.39 & 18.5 & 41.2 & 40.8 & 0.337 & 0.447 \\
\hline high & 13.4 & 8.09 & 17,5 & 41.9 & 41.6 & 0.318 & 0.415 \\
\hline \multicolumn{8}{|l|}{ Water status } \\
\hline stressed & 15.7 & 9.06 & 20.3 & 42.0 & 41.4 & 0.373 & 0.483 \\
\hline nonstressed & 12.4 & 6.80 & 16.6 & 39.8 & 39.7 & 0.312 & 0.418 \\
\hline \multicolumn{8}{|l|}{ Probability } \\
\hline Hybrid & ns & ns & ns & ns & ns & $\mathrm{ns}$ & ns \\
\hline $\mathrm{N}$ rate & ns & $* *$ & $*$ & $* *$ & * & $* *$ & **: \\
\hline Water stress & $* *$ & $* *$ & $* *$ & $* *$ & $*$ & $* *$ & $* *$ \\
\hline Hybrid $\times \mathrm{N}$ rate & ns & $\mathrm{ns}$ & ns & * & ns & $\mathrm{ns}$ & nis \\
\hline$N$ rate $\times$ stress & $* *$ & ** & $* *$ & $* *$ & * & $* *$ & $* *$ \\
\hline Hybrid $\times$ stress & ns & ns & ns & ns & ns & ns & $\mathrm{ns}$ \\
\hline Hybrid $\times N$ rate $\times$ stress & ns & $\mathrm{ns}$ & ns & ns & ns & ns & ns \\
\hline
\end{tabular}

*, ${ }^{* *}$ Significant at the 0.05 and 0.01 levels, significantly. 
Table 3: Correlation between chlorophyll meter readings of maize and ear leaf reflectance at several wavelengths.

\begin{tabular}{lc}
\hline $\begin{array}{l}\text { Wavelength } \\
(\mathrm{nm})\end{array}$ & $\begin{array}{l}\text { Correlation coefficient } \\
\text { (r) }\end{array}$ \\
\hline 550 & 0.77 \\
650 & 0.36 \\
710 & 0.78 \\
850 & $<0.03$ \\
940 & 0.05 \\
$550 / 850$ & 0.86 \\
$650 / 850$ & 0.46 \\
$710 / 850$ & 0.89 \\
$550 / 940$ & 0.83 \\
$650 / 940$ & 0.46 \\
$710 / 940$ & 0.84 \\
\hline
\end{tabular}

use this type of light (Fig. 3). For this reason, the near infrared portion of the spectrum is frequently used as a reference to normalize data collected at other wavelengths. In essence, infrared wavelengths tend to respond to factors other than those related to photosynthesis. Reflectance in the near infrared portion of the spectrum is influenced by the frequency of intercellular air spaces of leaf tissue, which is influenced by crop water status (Gausman et al., 1974). The effect of water stress on near infrared reflectance is illustrated in Figure 3. Thus, by referencing wavelengths that are responsive to photosynthetic activity and perhaps other unknown factors (i.e., 550,650 , and $710 \mathrm{~nm}$ ) to nonresponsive wavelengths (i.e., 850 and $940 \mathrm{~nm}$ ), the resulting ratio should improve the sensitivity of the reflectance measurement. Others have also used this technique to standardize their data (Takebe et al., 1990; Walburg et al., 1982). Correlations between both 550 and $710 \mathrm{~nm}$ and chlorophyll meter readings were improved by normalizing with data collected at either 850 or $940 \mathrm{~nm}$ (Table 3 ). The 850 -nm reference provided a slightly berter correlation with the other wavelengths than did the 940-nm wavelength. This observation could be an artifact because the instrumentation becomes insensitive at about $1050 \mathrm{~nm}$.

Normalized data using the $550 / 850 \mathrm{~nm}$ wavelengths has the advantage over other ratios because the reflectance patterns are broad at these wavelengths (Fig. 3). Data for this reflectance ratio exhibited a highly significant $\mathrm{N}$ by water stress interaction (Table 2). Regression analysis showed a strong inverse relationship between leaf $\mathrm{N}$ concentration and the $550 / 850$ reflectance ratio for the adequately watered plants (Fig. 4). This is because reflectance values at $550 \mathrm{~nm}$

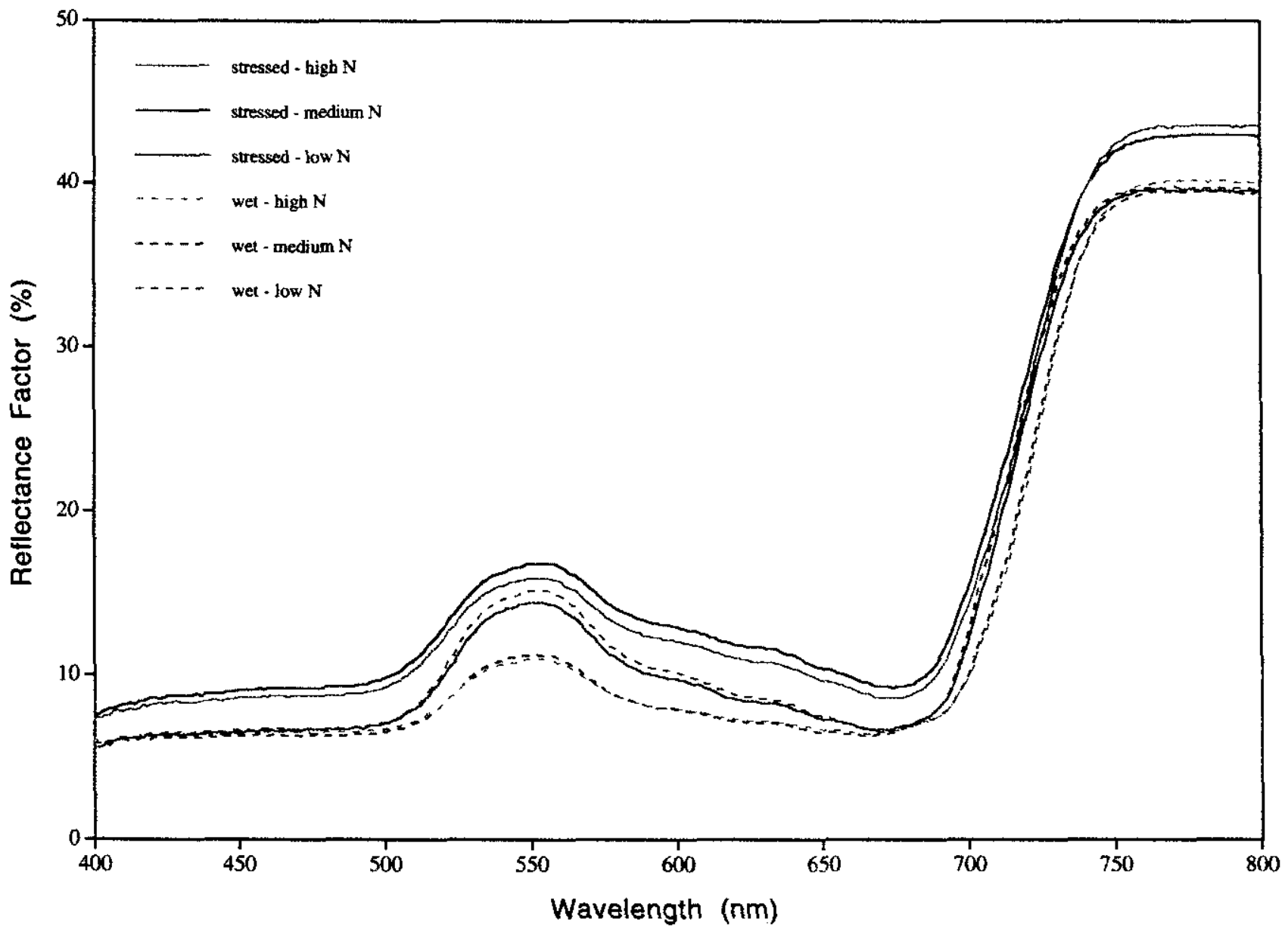

Fig. 3: Reflectance of corn ear-leaves at various wavelengths as affected by $\mathrm{N}$ level and water status. 

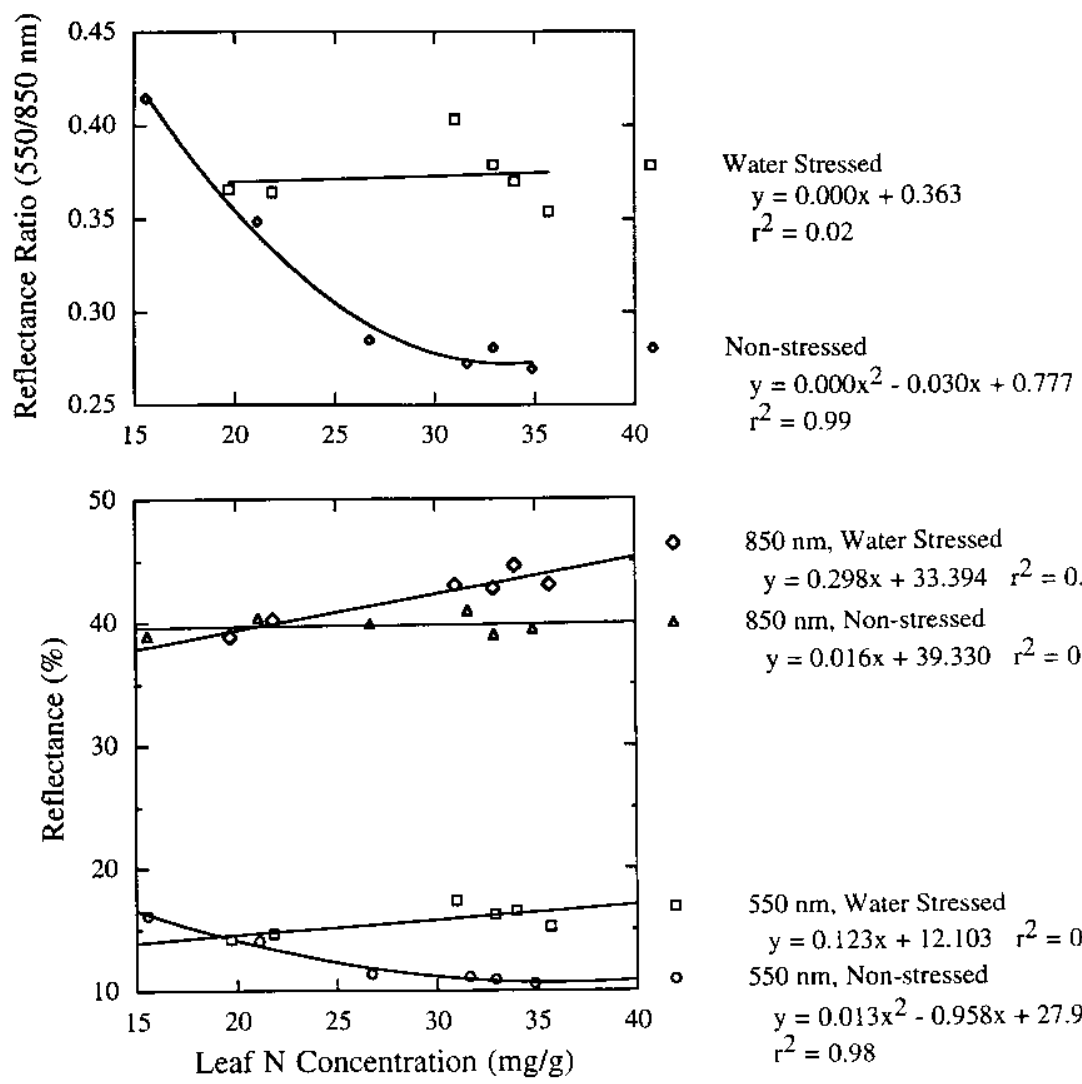

$550 \mathrm{~nm}$, Water Stressed
$y=0.123 x+12.103 \quad \mathrm{r}^{2}=0.47$
$550 \mathrm{~nm}$, Non-stressed
$y=0.013 \mathrm{x}^{2}-0.958 \mathrm{x}+27.958$
$\mathrm{r}^{2}=0.98$
Fig. 4: Ear-leaf reflectance at 550 and $850 \mathrm{~nm}$ and the ratio of $550 / 850 \mathrm{~nm}$ values for corn grown under water-stressed and control conditions as related to leaf $\mathrm{N}$ concentration. were highly correlated with leaf $\mathrm{N}$ concentration and values at $850 \mathrm{~nm}$ were unaffected by leaf $\mathrm{N}$ concentration. Water stress rendered reflectance values at $550 \mathrm{~nm}$ relatively insensitive to leaf $\mathrm{N}$ concentration while the reference values at $850 \mathrm{~nm}$ became sensitive to leaf $\mathrm{N}$ concentration. These findings raise serious concerns about the reliability of using reflectance measurements from water stressed plants to characterize crop $\mathrm{N}$ status. This conclusion may be an artifact of the experimental procedure because the plants used in the study had been under prolonged water stress at the time of measurement. Under more natural field conditions, plants would gradually change water content and would not likely remain under water stress for a prolonged period.

Values for the $550 / 850 \mathrm{~nm}$ reflectance ratio for adequately watered plants showed a strong inverse curvilinear relationship $\left(\mathrm{r}^{2}=0.97\right)$ with chlorophyll meter readings (Fig. 5). In contrast, the similar comparison for water stressed plants was very weak $\left(r^{2}=0.15\right)$. Questions remain regarding the effect of water stress on chlorophyll meter readings, but the effect of intercellular air spaces must be considered, as noted above. The observation that plants with high leaf $\mathrm{N}$ content had a relatively small effect on the value of the $550 / 850 \mathrm{~nm}$ ratio compared to more $\mathrm{N}$ deficient plants (Fig. 4) is attributed to a situation where other nutrients or growth factors limit leaf chlorophyll content at high leaf $\mathrm{N}$ levels. This effect carries over to the relationship between chlorophyll meter readings and the 550/850 reflectance ratio (Fig. 5).

The 940-nm wavelength was included in this study because the Minolta chlorophyll meter uses this wavelength for

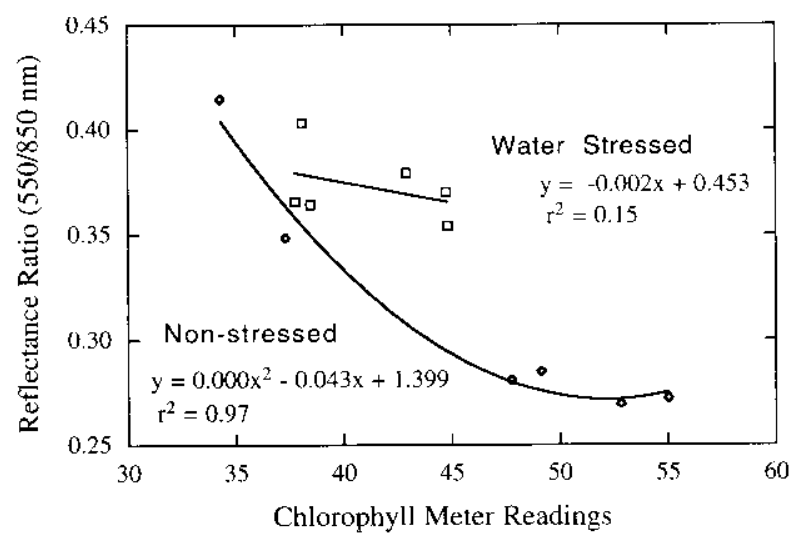

Fig. 5: Ear-leaf reflectance ratio of $550 / 850 \mathrm{~nm}$ values for corn grown under water-stressed and control conditions as related to chlorophyll meter readings.

calibration and normalizing light transmittance at $650 \mathrm{~nm}$. Details of signal handling at these wavelengths within the chlorophyll meter are not published. Data from this study showed a poor relationship between chlorophyll meter readings and the $650 / 940$ ratio $(r=0.44)$. Perhaps this rather poor relationship can be explained because both of these wavelengths were measured as reflected light in our study rather than using transmitted light as with the Minolta chlorophyll meter. Another contributing factor may be that the Minolta 
meter measures the amount of light transmitted through a 2 by $3 \mathrm{~mm}$ segment of the leaf. The rest of the light is either absorbed by the leaf or reflected into the closed chamber around the leaf.

In practical terms, the shape of a reflectance trace as a function of wavelength needs to be considered when evaluating the feasibility of developing a simple and inexpensive sensor system. The peaks at 550 and $650 \mathrm{~nm}$ are quite broad and the plateau in the near infrared range (i.e., 850 and $940 \mathrm{~nm}$ ) make these wavelengths good candidates for further consideration (Fig. 2). Even though reflectance at $710 \mathrm{~nm}$ is quite specific for photosynthesis, the narrowness of the band may make it difficult to develop a sensor that would be accurate as well as reliable.

\section{Conclusions}

Common laboratory procedures that quantify crop $\mathrm{N}$ status were able to detect differences in soil $\mathrm{N}$ availability of corn leaves at silking as they responded to water stress. A hand-held chlorophyll meter provided similar information relative to crop $\mathrm{N}$ status. Chlorophyll meters make gathering crop $\mathrm{N}$ status information faster and easier than traditional laboratory techniques. Reflectance measurements offer the potential to evaluate the $\mathrm{N}$ status of a single leaf by using an integrating sphere or an entire crop canopy using a spectroradiometer. Canopy type measurements have many advantages compared to single leaf measurements afforded by the $\mathrm{Mi}$ nolta chlorophyll meter. Even though reflectance measurements taken in this study involved a closed chamber instrument (i.e., integrating sphere) that would be impractical and expensive to use under commercial applications, the results indicate that the concept of measuring leaf reflectance to evaluate crop $N$ status is sound. Normalizing reflectance data at $550 \mathrm{~nm}$ to the $850 \mathrm{~nm}$ wavelength (i.e., $550 / 850$ ratio), should provide a reasonable measure of crop $\mathrm{N}$ status over a range of water regimes.

\section{References}

Abacus Concepts, Inc.: SuperANOVA Users Manual. Berkeley, California 94704 (1989)

Al-Abbas, A. H., R. Barr, J. I. Hal.I, F. L. Crane, and M. F. Baumgardner: Spectra of normal and nutrient-deficient corn leaves. Agron. J. 66, 16-20 (1974).

Benedict, H. M. and R. Swidler: Nondestructive methods for estimating chlorophyll content of leaves. Science 133, 2015-2016 (1961)

Blackmer, T. M. and J. S. Schepers: Use of a chlorophyll meter to monitor $\mathrm{N}$ status and schedule fertigation of corn. J. Prod. Agric. $8,56-60(1995)$.

Blackmer, T. M., J. S. Schepers, and G. E. Varyel: Light reflectance compared to other $\mathrm{N}$ stress measurements in corn leaves. Agron. J. 86, 934-938 (1994).

Chappelle, E. W., M. S. Kim, and J. E. McMurtrey: Ratio analysis of reflectance spectra (RARS): an algorithm for the remote es- timation of the concentrations of chlorophyll $a$, chlorophyll $b$, and carotcnoids in soybean leaves. Remote Sens. Environ. 39, 239-247 (1992).

Francis, D. D., J. S. Schepers, and M. F. VIGIL: Post-anthesis nirogen loss from corn plants. Agron. J. 85, 659-663 (1993).

Gausman, H. W., W. A. Allen, and D. E. Escobar: Refractive index of plant cell walls. Applied Optics 13, 109-111 (1974).

Hauck, R. D.: Nitrogen - Isotopic-Ratio Analysis. In: PAGe, A. I. (ed.): Methods of Soil Analysis. Number 9, Part 2, pp. 735-779. Am. Soc. Agron., Madison, Wisconsin (1982).

MAas, S. J. and J. R. DunlaP: Reflectance, transmittance, and absorptance of light by normal, etiolated, and albino corn lcaves. Agron. J. 81, 105-110 (1989).

McMurtrey, J. E., III, E. W. Chappelle, M. S. Kim, J. J. MeisinGER, and L. A. CORP: Distinguishing nitrogen fertilization levels in field corn [Zea mays L.] with actively induced fluorescence and passive reflectance measurements. Remote Sens. Environ. 47, 36-44 (1994).

Peiterson, T. A., T. M. Blackmer, D. D. Francis, and J. S. SchePERS: Using a chlorophyll meter to improve $\mathrm{N}$ management. Nebguide G93-1171A. Coop. Ext. Serv., Univ, of Nebraska, Lincoln (1993).

Ritchie, S. E., J. J. Hanway, and G. O. Benson: How a corn plant devclops. Iowa Cooperative Extension Service Special Report 48, Iowa State University, Ames, Iowa (1992).

Schepers, J. S., D. D. Francis, and M. T. Thompson: Simultaneous determination of total $\mathrm{C}$, total $\mathrm{N}$, and ${ }^{15} \mathrm{~N}$ on soil and plant material. Commun. Soil Plant Anal. 20, 949-960 (1989).

Schepers, J. S., T. M. Blackmer, and I). D. Francis: Predicting N fertilizer needs for corn in humid regions: using chlorophyll meters. In: Bock, B. R. and K. R. Kelley (eds.): Predicting Fertilizer Needs for Corn in Humid Regions. Bull. Y-226. pp. 105-114. National Fertilizer and Environmental Research Center, 'Tennessee Valley Authority, Muscle Shoals, AL 35660 (1992a).

Schepers, J. S., D. D. Francis, M. Vigil., and F. E. Brzow: Comparison of corn leaf nitrogen concentration and chlorophyll meter readings. Comm. Soil Plant Anal. 23, 2173-2187 (1992 b).

Sinclair, T. R., R. M. Hoffer, and M. M. Schrfiber: Reflectance and internal structure of leaves from several crops during a grosing season. Agron. J. 63, 864-868 (1971).

Takebe, M., T. Yoneyama, K. Inada, and '1. Murakam: Spectral reflectance of rice canopy for estimating crop nitrogen status. Plant and Soil. 122, 295-297 (1990).

Thomas, J. R. and H. W. Gausman: Leaf reflectance vs. leaf chlorophyll and carotenoid concentration for eight crops. Agron. J. 69, 799-802 (1977)

Thomas, J. R. and G. F. Oerther: Estimating nitrogen content of sweet pepper leaves by reflectance measurements. Agron. J. 64, 11-13 (1972).

Walburg, G., M. E. Bauer, C. S. T. Daughtry, and T. L. Houst.EY: Effects of nitrogen nutrition on the growth, yield, and reflectance characteristics of corn canopies. Agron. J. 74, 677-683 (1982).

Wolfe, D. W., D. W. Henderson, T. C. Hsiao, and A. Alvino: Interactive water and nitrogen effects on senescences of corn. II. Photosynthetic decline and longevity of individual leaves. Agron. J. 80, 865-870 (1988).

Wood, C. W., D. W. Reeves, R. R. Duffield, and K. L. EdMISTEN: Field chlorophyll measurements for evaluation of corn nitrogen status. J. Plant Nutr. 15, 487-500 (1992).

Woolley, J. T.: Reflectance and transmittance of light by leaves. Plant Physiol. 47, 656-662 (1971). 